\title{
Durabilité des géotextiles aramides en milieu alcalin
}

\author{
Derombise Guillaume ${ }^{1,}{ }^{*}$, Van Schoors Laetitia ${ }^{1}$, Davies Peter ${ }^{2}$
}

1 Lab Cent Ponts \& Chaussees, F-75732 Paris 15, France.

2 IFREMER, Ctr Brest, F-29280 Plouzane, France.

* Corresponding author : Guillaume Derombise, email address : quillaume.derombise@lcpc.fr

\begin{abstract}
:
Because of their high initial properties, aramid geotextiles have been used for a decade for ground reinforcement. Today, the geotextiles manufacturers think about their use in alkaline grounds. However there are few data on the long-term behaviour of aramid fibres under these conditions. Consequently, a durability study in a basic environment has been carried out in order to improve understanding of the degradation mechanisms involved in ageing. On that purpose, the physico-chemical characteristics as well as the surface state and the mechanical properties of the Twaron 1000 fibres have been followed at different ageing times.
\end{abstract}

\section{Résumé :}

Du fait de leurs propriétés initiales élevées, les géotextiles à base de fibres aramides sont utilisés depuis une dizaine d'années pour le renforcement des sols. Aujourd'hui, les fabricants de géotextiles envisagent leur utilisation dans les sols alcalins. Cependant le comportement à long terme des fibres aramides dans ces conditions est encore mal connu. Une étude de durabilité en milieu basique a donc été initiée afin d'apporter une compréhension approfondie des mécanismes de dégradation mis en jeu. Ainsi, les caractéristiques physico-chimiques, l'état de surface, de même que les propriétés mécaniques des fibres Twaron 1000 ont été suivis à différents temps de vieillissement.

Keywords : Durability, Alkaline ground, Ageing, Reinforcement, Geotextile, Fibre, Aramid

Mots-clés : aramide, fibre, géotextile, renforcement, vieillissement, sol alcalin, durabilité 
A few years ago, geotextiles based on polyethylene terephtalate fibres were commonly used for alkaline ground reinforcement applications. However, when these were observed to display premature ageing under these conditions (lime, cement or slag treated soils, next to the skin of hardened concrete, etc...), alternative solutions were developed, among which are geotextiles made of Technora [Auray et al., 2007; Blivet et al., 2006] and Twaron fibres. The molecular structures are given in Figure 1. Technora fibres are based on copoly-(paraphenylene/3,4'-oxydiphenylene terephtalamide). Imuro and Yoshida [Imuro et al., 1986] proposed a structural model for Technora fibres (HM-50 grade) consisting of both random sequences in an alternating distribution and block copolymer parts. The well-oriented and fully-extended macromolecular chains are composed of $70-90 \AA$ long flexible segments (made of 3-4' POP sequences) and 110-130 $\AA$ long rigid segments (made of PPTA sequences). Technora fibres do not display any skin-core structure. Twaron fibres are based on poly( $p$-phenylene terephtalamide) (PPTA). Panar et al. [Panar et al., 1983] proposed a microstructural model composed of a fibrillar structure with a high proportion of extended chains passing through periodic chain-ends layers, a surimposed pleat structure, and a skin-core structure.

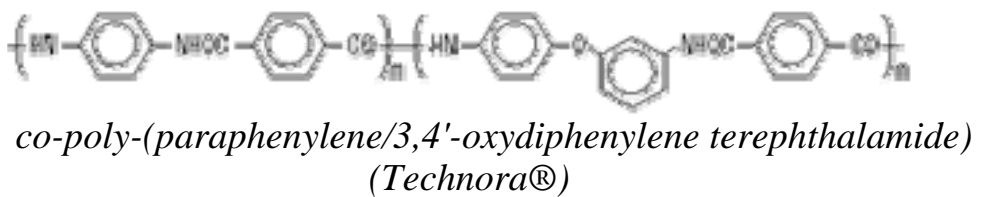

(Technora ${ }^{\circledR}$ )

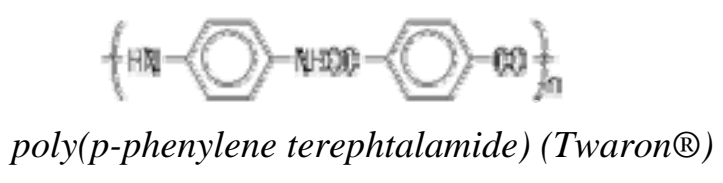

Figure I. Aramid molecular structures

The high tensile modulus and tensile strength [Yang, 1989 ; Yang, 1993] of aramid fibres combined with a good chemical resistance in most organic solvents and aqueous salt solutions [Yang, 1993; Teijin] and a low density [Teijin] make them an interesting option for civil engineering applications such as geotextiles. However, Twaron and Technora fibres are both sensitive towards hydrolysis. Hydrolysis of PPTA involves a scission of the amide $\mathrm{N}-\mathrm{C}$ linkage, yielding acid and amine functions, Figure 2 [Morgan et al., 1984].

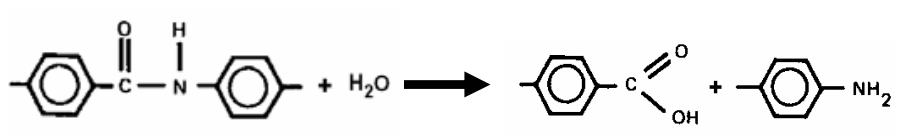

Figure II. Hydrolysis of PPTA

Imuro and Yoshida [Imuro et al., 1986] reported that the tensile strength of Technora (HM-50) fibres does not decrease after 400 hours exposure in $120^{\circ} \mathrm{C}$ saturated steam, whereas it decreases by $80 \%$ for PPTA fibres. In a similar way, the tensile strength of Technora fibres decreases by $25 \%$ after 100 hours exposure in a 10 wt $\% \mathrm{NaOH}$ solution at $95^{\circ} \mathrm{C}$, whereas it decreases by $80 \%$ for PPTA 
fibres. However there are no published data on the long-term behaviour of aramid fibres aged in moderately alkaline solutions. This work aims at identifying hydrolysis degradation of Twaron and Technora fibres aged at $\mathrm{pH} 9$ and $\mathrm{pH} 11$, and to propose a first suggestion for an alternative to PET geotextiles in treated ground.

\section{Experimental}

\subsection{Materials}

Two kinds of aramid fibres, produced by Teijin Aramid, were studied in this paper: Twaron 1000 fibres, in the form of 1680 dtex yarn, and Technora T240 fibres, in the form of 1670 dtex yarn.

\subsection{Ageing methods}

Yarns were studied in two ageing environments. Yarn samples were immersed in buffer carbonate sodium salt solutions at pH9 and pH11. Four temperatures have been considered for each ageing condition: $20,40,60$ and $80^{\circ} \mathrm{C}$. Over the ageing period considered here the temperature variability is estimated at $+/-2^{\circ} \mathrm{C}$.

\subsection{Analysis and characterization}

\subsubsection{Viscosity measurements}

Viscosity measurements were carried out using an Ubbelhode DIN (Schott Instruments) capillary viscosimeter, at $25^{\circ} \mathrm{C}$. For Twaron fibres, the weight average molecular mass was calculated from the Mark-Houwink relationship established by Arpin and Strazielle: $\eta=$ $8 \times 10^{-3} \mathrm{M}^{1.09}$ [Arpin et al., 1977]. For that purpose, four concentrations between $5.10^{-4} \mathrm{~g} / \mathrm{mL}$ and $2.10^{-3} \mathrm{~g} / \mathrm{mL}$ were chosen. The reduced viscosity comparisons were performed for the latter concentration. The fibres were previously dissolved in sulphuric acid concentrated at $96 \%$, for two hours at $60^{\circ} \mathrm{C}$ with magnetic stirring. Above this dissolution temperature, additional degradation can occur in sulphuric acid [Aoki et al., 1979].

For Technora fibres, the reduced viscosities measurements were performed from three concentrations between $3.10^{-4} \mathrm{~g} / \mathrm{mL}$ and $1.5 .10^{-}$ ${ }^{3} \mathrm{~g} / \mathrm{mL}$. $25 \mathrm{mg}$ to $75 \mathrm{mg}$ of material were weighed and dissolved in 50 $\mathrm{mL}$ of sulphuric acid concentrated at $96 \%$, for two hours at $60^{\circ} \mathrm{C}$ with magnetic stirring. Because of the presence of ether linkages, Technora fibres are more susceptible to strong acid exposure than are pure aramids Twaron fibres [Ozawa, 1987]. The remaining insoluble fractions after dissolution were extracted and weighed to calculate the true concentration of the solution.

\subsubsection{Tensile tests}

The tensile tests were performed on unitary fibres using a Zwick 1474 tensile testing machine with a $5 \mathrm{~N}$ force sensor and a rate of extension of $\sim 10 \% / \mathrm{min}$, at $20^{\circ} \mathrm{C}$. The fibre diameter, $\sim 12 \mu \mathrm{m}$ on average, was measured before each test using a laser micrometer Mitutoyo LSM$500 \mathrm{~S}$ mounted on the tensile testing machine. The precision of the measurement is $+/-0.1 \mu \mathrm{m}$. Around fifteen valid tests were 
considered for each condition and duration of ageing. The tensile modulus was calculated between 0.3 and $0.6 \%$ elongation.

\section{Results and discussion}

After evaluating the bulk degradation of Twaron and Technora fibres by viscosity measurements, the influence of potential chain scission phenomena on the mechanical properties will be studied.

\subsection{Evaluation of the bulk degradation}

\subsubsection{Twaron fibres}

The weight average molecular mass of as-received Twaron 1000 fibres is $-32,000 \mathrm{~g} / \mathrm{mol}$. However, the reduced viscosity at $0.2 \mathrm{~g} / \mathrm{dL}$ is a more precise indicator to highlight low degradation rates as it does not require any extrapolation.

Figure $3 \mathrm{a}$ and $3 \mathrm{~b}$ present the decrease in the reduced viscosity at $\mathrm{pH} 11$ and $\mathrm{pH} 9$.

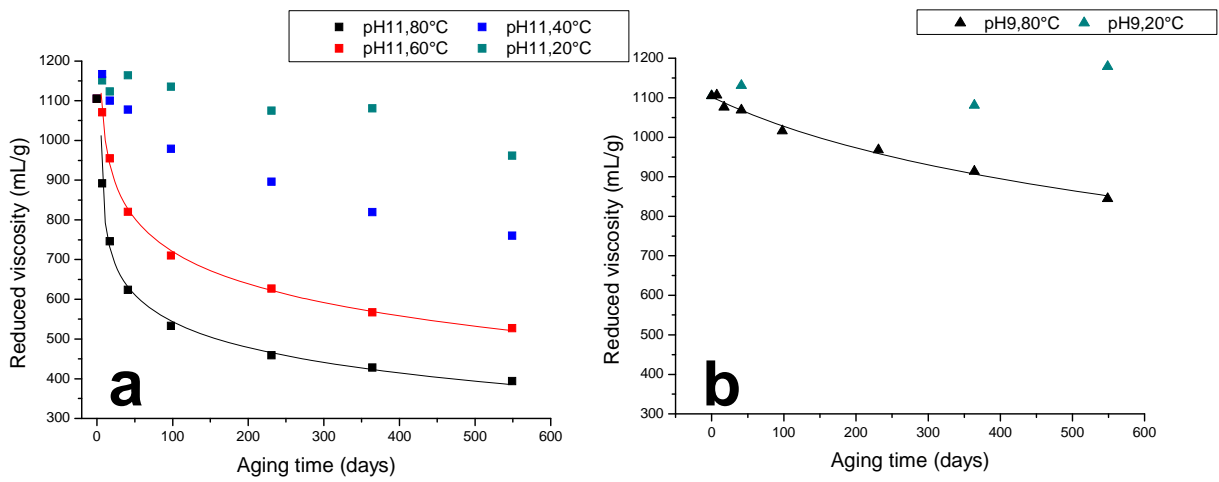

Figure III. Evolution of the reduced viscosity of Twaron 1000 fibres at $0.2 \mathrm{~g} / \mathrm{dL}$ at $\mathrm{pH} 11$ and $\mathrm{pH} 9$

At $\mathrm{pH} 11$, the reduced viscosity follows a logarithmic evolution with time at 40,60 and $80^{\circ} \mathrm{C}$. It appears that the higher the temperature, the higher the degradation rate. The reduced viscosity decreases by $64 \%$ at $80^{\circ} \mathrm{C}$, whereas it decreases by $13 \%$ at $20^{\circ} \mathrm{C}$. At $\mathrm{pH} 9$ and $80^{\circ} \mathrm{C}$, the reduced viscosity follows a logarithmic evolution with time, and is relatively constant after one and half years ageing at $\mathrm{pH} 9$ and $20^{\circ} \mathrm{C}$.

The reduced viscosity degradation curves confirm that hydrolysis is accelerated by temperature [Morgan et al., 1984]. It is also shown that the hydrolytic environment has a significant influence on the degradation: the degradation is larger at $\mathrm{pH} 11$ than at $\mathrm{pH} 9$. The data can be fitted to logarithmic laws, and modelled by Springer et al.'s equation (1) [Springer et al., 1998] (to which an additional constant term has been added), established for tensile strength evolutions after different aggressive hydrolytic treatments.

$$
\sigma=\sigma_{0}\left(\alpha_{1} \exp \frac{-t}{\tau_{1}}+\alpha_{2} \exp \frac{-t}{\tau_{2}}\right)
$$


where $\alpha_{1}$ and $\alpha_{2}$ represent the amounts, and $\tau_{1}$ and $\tau_{2}$ the decay times of the two processes respectively. These two processes were assigned by the authors to two different fibre regions (core and shell or crystalline and non-crystalline regions) or to structural elements being stressed differently (loose and taut tie molecules). For Twaron 1000 fibres aged at $\mathrm{pH} 9$ only one decay function suffices to fit the data. At pH11, two decay functions are needed. The logarithmic evolutions observed here have been previously interpreted as the result of two degradation processes at $\mathrm{pH} 11$, namely the destruction of the tie-molecules/fibrils and the degradation of the crystallites, and one degradation process at $\mathrm{pH}$, namely the destruction of the tiemolecules/fibrils only [Derombise et al., a].

\subsubsection{Technora fibres}

The reduced viscosity of Technora $T 240$ increases slightly from $\sim 441$ to $\sim 497 \mathrm{~mL} / \mathrm{g}$ after one year at $\mathrm{pH} 11$ and $80^{\circ} \mathrm{C}$ and from $\sim 441$ to $\sim 450 \mathrm{~mL} / \mathrm{g}$ after one year at $\mathrm{pH} 9$ and $80^{\circ} \mathrm{C}$.

Previous studies revealed that the presence of finish lowers significantly the reduced viscosity of Technora fibres [Derombise et al., b]. Indeed, the finish used here must be a low molecular weight compound that would decrease the global reduced viscosity [Derombise et al., b]. As the reduced viscosity evolution of aged Technora T240 fibres may result from a complex combination of finish removal and potential chain scissions, it is impossible to evaluate the Technora T240 bulk degradation reliably.

\subsection{Tensile property evolution}

Tensile tests permit to characterise the functional properties of aramid fibres, namely the tensile strength and the tensile modulus.

\subsubsection{Tensile strength}

\subsubsection{Twaron 1000}

Figure $4 \mathrm{a}$ and $4 \mathrm{~b}$ present the tensile strength evolution of Twaron 1000 fibres at $\mathrm{pH} 11$ and $\mathrm{pH}$. No significant evolution of the diameter of Twaron 1000 fibres, measured by laser micrometer, was observed even after exposure for one and half years for all ageing conditions.
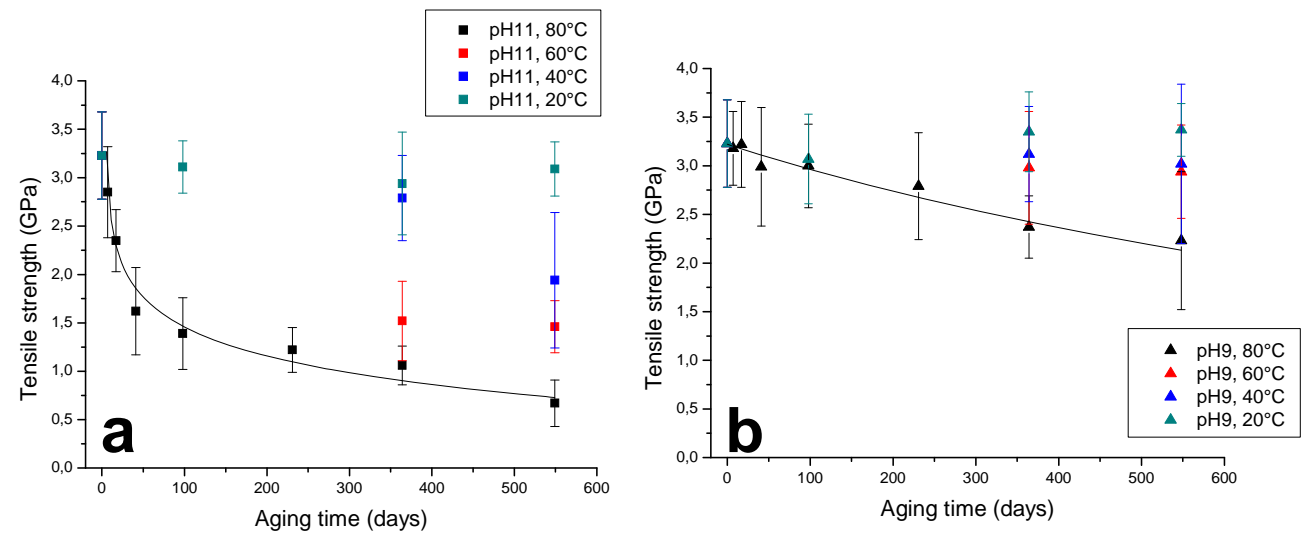

Figure IV. Evolution of the tensile strength of Twaron 1000 fibres with ageing time at (a) $\mathrm{pH} 11$ and (b) $\mathrm{pH} 9$ 
At $\mathrm{pH} 11$, the tensile strength degradation follows the same logarithmic evolution as the reduced viscosity. In a similar way, the higher the temperature, the larger the degradation: the tensile strength decreases by $\sim 80 \%$ at $80^{\circ} \mathrm{C}$, whereas it decreases by only $\sim 5 \%$ at $20^{\circ} \mathrm{C}$. At $\mathrm{pH}$, the tensile strength degradation follows, to a first approximation, a linear relation with ageing time. As at $\mathrm{pH} 11$, the higher the temperature, the larger the degradation: the tensile strength decreases by $\sim 30 \%$ at $80^{\circ} \mathrm{C}$ after one and half years ageing, whereas it is stable at $20^{\circ} \mathrm{C}$.

As for bulk degradation, the tensile strength degradation is accelerated by temperature. The degradation also depends on the ageing conditions: the more the environment is basic, the larger is the tensile strength degradation. As the tensile strength and the reduced viscosity seem to follow similar evolutions, they must be closely related. Figure 5 plots the reduced viscosity measured at $0.2 \mathrm{dL} / \mathrm{g}$ versus the tensile strength.

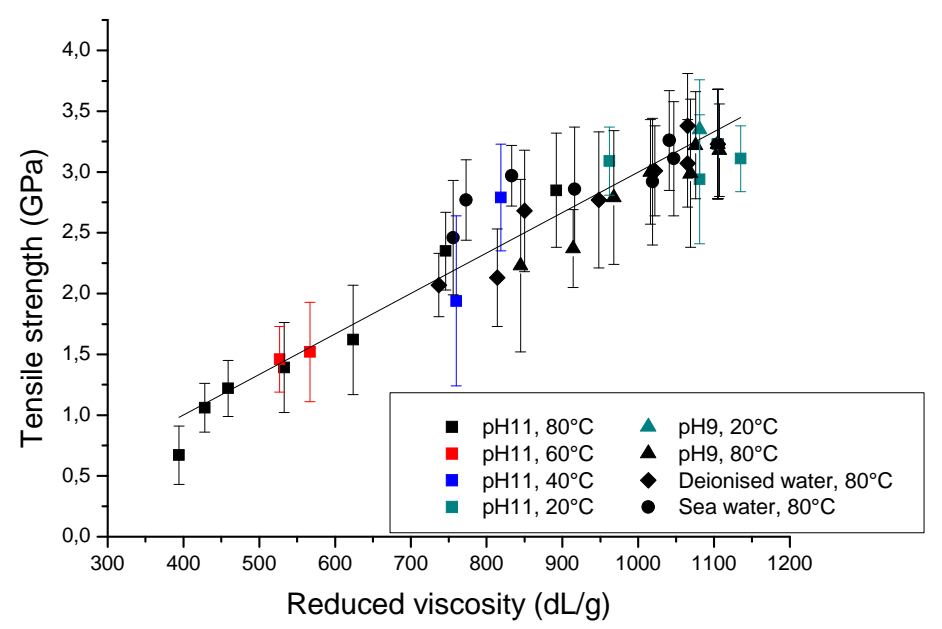

Figure V. Relation between the reduced viscosity at $0.2 \mathrm{~g} / \mathrm{dL}$ and the tensile strength of Twaron 1000 fibres aged under different conditions It appears that to a first approximation these two characteristics can be correlated using a linear relationship, which is in accordance with a previous study [Weyland, 1980].

This result supports that that the tensile strength is governed by the lateral intermolecular bonds, as presumed by Yoon [Yoon, 1990]. Indeed, as the hydrolytic degradation progresses, the concentration of amide functions decreases, and consequently, the probability of formation of $\mathrm{H}$-intermolecular bonding is reduced resulting in a decrease in the tensile strength.

\subsubsection{Technora $\mathrm{T} 240$}

Table 1 presents the tensile strength evolution of Technora T240 after one and half years ageing in all conditions. No significant evolution of the diameter of Technora T240 fibres, measured by laser micrometer, was observed even after one and half years exposure in all ageing conditions. 


\begin{tabular}{|c|c|c|}
\cline { 3 - 3 } \multicolumn{2}{c|}{} & \multicolumn{2}{l|}{ Tensile strength (GPa) } \\
\hline \multicolumn{2}{|c|}{ As-received } & $3.7 \pm 0.5$ \\
\hline \multirow{2}{*}{$\mathrm{pH} 11$} & $20^{\circ} \mathrm{C}$ & $3.7 \pm 0.4$ \\
\cline { 2 - 3 } & $80^{\circ} \mathrm{C}$ & $3.3 \pm 0.3$ \\
\hline \multirow{2}{*}{$\mathrm{pH} 9$} & $20^{\circ} \mathrm{C}$ & $3.7 \pm 0.3$ \\
\cline { 2 - 3 } & $80^{\circ} \mathrm{C}$ & $3.6 \pm 0.3$ \\
\hline
\end{tabular}

Table I. Tensile strength of Technora T240 fibres after one and half years ageing

The decrease in the tensile strength reaches $\sim 10 \%$ at $\mathrm{pH} 11$ and $80^{\circ} \mathrm{C}$, and is lower for all the other conditions.

Figure 6 presents the evolution of the tensile strength of Technora T240 fibres aged at $\mathrm{pH} 11$ at different temperatures. As for Twaron 1000 fibres the tensile strength follows a logarithmic relation with time at $\mathrm{pH} 11$ and $80^{\circ} \mathrm{C}$. The tensile strength is stable at $\mathrm{pH} 11$ and $20^{\circ} \mathrm{C}$, even after one and half years ageing. It appears that the higher the temperature, the lower the tensile strength.

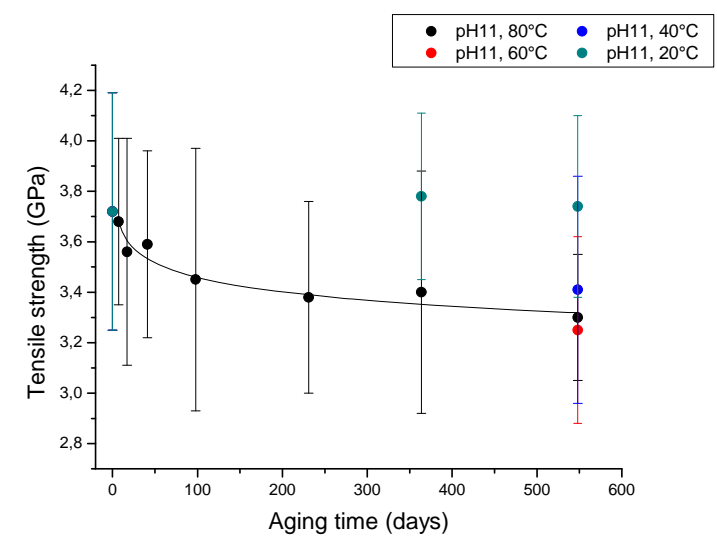

Figure VI. Tensile strength evolutions of Technora T240 fibres aged at $\mathrm{pH} 11$

The tensile strength degradations of Technora T240 fibres aged at $\mathrm{pH} 11$ and $80^{\circ} \mathrm{C}$ can be fitted with Springer et al.'s equation (1) [Springer et al., 1998], described in the previous section, using one decay function: only one degradation process has thus to be considered. This is consistent with the homogeneous structure of Technora fibres, which, contrary to PPTA fibres, do not display any skin-core structure [Imuro et al., 1986; Panar et al., 1983]. For all the other conditions, the evolutions in the tensile strength are too small to be fitted.

\subsubsection{Comparison Technora T240/Twaron 1000 fibres}

Figure 7 groups the tensile strength evolution of Twaron 1000 and Technora $\mathrm{T} 240$ fibres aged at $\mathrm{pH} 9$ and $\mathrm{pH} 11$ at $80^{\circ} \mathrm{C}$. 


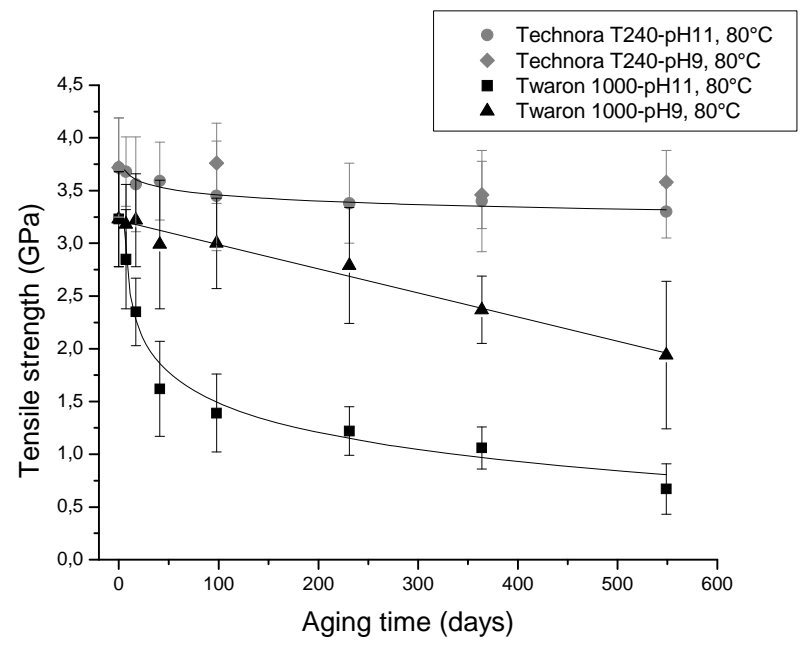

Figure VII. Tensile strength evolutions of Twaron 1000 and Technora fibres aged at $\mathrm{pH} 9$ and $\mathrm{pH} 11$ at $80^{\circ} \mathrm{C}$

It appears that the decrease in the tensile strength is considerably larger for Twaron than for Technora fibres, both at $\mathrm{pH} 11$ and at $\mathrm{pH}$. Imuro and Yoshida [Imuro et al., 1986] explained the better hydrolysis resistance of Technora fibres by the introduction of less chemicallyreactive ether-linkages in the molecular structure, as well as a highly oriented and uniform dense structure that prevent water from penetrating into the fibre.

\subsubsection{Tensile modulus}

Table 2 groups the tensile modulus after one and half years ageing for all the conditions.

\begin{tabular}{|l|l|l|l|}
\cline { 3 - 4 } \multicolumn{2}{c|}{} & \multicolumn{1}{l|}{$\begin{array}{l}\text { Twaron } \\
1000\end{array}$} & $\begin{array}{l}\text { Technora } \\
\text { T240 }\end{array}$ \\
\hline \multirow{2}{*}{ As-received } & $80 \pm 11 \mathrm{GPa}$ & $79 \pm 7 \mathrm{GPa}$ \\
\hline $\mathrm{pH} 11$ & $20^{\circ} \mathrm{C}$ & $81 \pm 10 \mathrm{GPa}$ & $86 \pm 9 \mathrm{GPa}$ \\
\cline { 2 - 4 } & $80^{\circ} \mathrm{C}$ & $-^{*}$ & $83 \pm 6 \mathrm{GPa}$ \\
\hline \multirow{2}{*}{$\mathrm{pH} 9$} & $20^{\circ} \mathrm{C}$ & $81 \pm 14 \mathrm{GPa}$ & $88 \pm 10 \mathrm{GPa}$ \\
\cline { 2 - 4 } & $80^{\circ} \mathrm{C}$ & $85 \pm 9 \mathrm{GPa}$ & $86 \pm 9 \mathrm{GPa}$ \\
\hline
\end{tabular}

* The modulus cannot be measured, as the deformation at break is lower than $0.6 \%$. Howerver the modulus is $84 \pm 8 \mathrm{GPa}$ after one year ageing under this ageing condition.

Table II. Tensile modulus of Twaron 1000 and Technora T240 fibres after one and half years ageing

The tensile modulus of Twaron 1000 and Technora T240 fibres does not display any significant evolution after ageing in all conditions. Northolt et al. [Northolt et al., 2005] have proposed a relation between the strength and the modulus of well-oriented PPTA, which is in accordance with their experimental data: tensile strength increases with modulus. In a similar way, Young et al. [Young et al., 1992] show that the tensile strength of aramid fibres increases with modulus. The experimental data obtained in the present study do not show this trend. 
As it is known that the modulus of high performance fibres is governed by the chain orientations [Northolt et al., 2005; Young et al., 1992], one can conclude that the macromolecular chains retain their initial orientation during ageing.

\section{Conclusions}

The long-term behaviour of Technora T240 and Twaron 1000 fibres in an alkaline environment has been studied using accelerated ageing at $\mathrm{pH} 11$ and $\mathrm{pH}$. The fibres were characterized by viscosimetry and tensile tests for up to one and half years ageing to evaluate the degradation and to give a better insight into the degradation mechanisms. From this work several points may be concluded:

\section{Twaron 1000}

- The degradation in an alkaline environment involves a slow chain degradation rate at $\mathrm{pH} 9$ and an important chain degradation rate at $\mathrm{pH} 11$. The degradation seems to follow a logarithmic relation with time.

- The decrease in the tensile strength is significantly higher at $\mathrm{pH} 11$ than at $\mathrm{pH}$ : it reaches $80 \%$ after one and half years at $\mathrm{pH} 11$ and $80^{\circ} \mathrm{C}$, whereas it is $30 \%$ at $\mathrm{pH} 9$ and $80^{\circ} \mathrm{C}$. There is a linear relation between the tensile strength and the reduced viscosity of Twaron 1000 fibres aged in an alkaline environment.

- No change in modulus has been observed during ageing.

\section{Technora T240}

- No evidence of chain degradation was observed because of a large influence of the finish on the calculated reduced viscosity.

- A slight decrease in the tensile strength has been observed at $\mathrm{pH} 11$; the decrease is lower at $\mathrm{pH} 9$. Indeed, the decrease reaches only $10 \%$ after one and half years at $\mathrm{pH} 11$ and $80^{\circ} \mathrm{C}$, and $4 \%$ after one and half years at $\mathrm{pH} 9$ and $80^{\circ} \mathrm{C}$.

- The modulus remains constant during ageing.

Finally a comparison between the long-term behaviour of Twaron 1000 and Technora T240 fibres has been presented: with respect to the tensile strength conservation, Technora T240 fibres appear to be much more resistant to moderate alkaline environment than Twaron 1000 fibres. Now the accelerated ageing in the laboratory must be related to real application conditions, in order to conclude on the possibility of using Twaron 1000 fibres for applications where the required lifetime may be 100 years.

\section{Acknowledgments}

The authors acknowledge Nicolas Barberis, Dominique Duragrin (LCPC) and Nicolas Lacotte (IFREMER) for their high involvement in the study presented here. The authors are also grateful to Otto Grabandt and Bertil van Berkel of Teijin Aramid for the samples and their cooperation. 


\section{References}

Aoki H., Onogi Y., White J. L., Fellers J. F., « Liquid crystalline aromatic polyamides: characterization and extrusion of blown film and ribbon $», 37^{\text {th }}$ Annual Technical Conference Society of Plastics Engineers, New Orleans, 1979.

Arpin M. and Strazielle C., « Characterization and conformation of aromatic polyamides: poly( $p$-phenylene terephtalamide) and poly ( $p$ benzamide) in sulphuric acid », Polymer, 18, 1977, p. 591-598.

Auray G., and Simons D., " Geotextiles: essential reinforcement », JEC Composites Magazine, 35, 2007, p. 58-61.

Blivet J.-C., Garcin P., Hirschauer A., Nancey A., and Villard P., « Renforcement par géosynthétique sur cavités potenielles: exemples de la déviation sud-ouest de Meaux (77) », Rencontres géosynthétiques, Montpellier, 2006.

Derombise G., Van Schoors Vouyovitch L., and Davies P., « Degradation of aramid fibres under alkaline and neutral conditions: relations between physico-chemical characteristics and mechanical properties ». To be submitted, a.

Derombise G., Messou M.-F., Van Schoors Vouyovitch L., and Davies P., " Influence of finish treatment on the durability of aramid fibres aged under an alkaline environment ». To be submitted, $b$. Imuro H., and Yoshida N., « Differences between HM-50 and PPTAAramides », 25th International Man Made Fibres Congress, Dornbirn, 1986.

Morgan R. J, Pruneda C. O., Butler N., Kong F.-M., Caley L., and Moore R. L., « The hydrolytic degradation of Kevlar 49 fibers », $29^{\text {th }}$ National sampe Symposium, 1984.

Northolt M.G., den Decker P., Picken S. J., Baltussen J. J. M., and Schlatmann R., « The Tensile Strength of Polymer Fibres ». Advances in Polymer Science, 178, 2005, p. 1-108.

Ozawa S., « A new approach to high modulus, high tenacity fibers ». Polymer Journal,19 (1), 1987, p. 119-125.

Panar M., Avakian P., Blume R. C., Gardner K. H., Gierke T. D., and Yang H. H., "Morphology of Poly(p-phenylene Terephtalamide) Fibers ». Journal of Polymer Science: Polymer Physics Edition, 21, 1983, p. 1955-1969.

Springer H., Abu Obaid A., Prabawa A. B., and Hinrichsen G., « Influence of Hydrolytic and Chemical Treatment on the Mechanical Properties of Aramid and Copolyaramid Fibers », Textile Research Journal, 8(68), 1998, p. 588-594.

Teijin, Technora ${ }^{\circledR}$ - High Tenacity Aramid Fiber.

Weyland H.G., " The Effect of Anisotropy in Wet Spinning Poly(P-Phenyleneterephtalamide) », Polymer Bulletin, 3, 1980, p. 331-337.

Yang H. H., Aromatic high strength, Ed. Wiley interscience, 1989, p. 226-289.

Yang H. H., Kevlar Aramid Fiber, Ed. John Wiley \& Sons, 1993.

Yoon H. N., " Strength of fibers from wholly aromatic polyesters », Colloid \& Polymer Science, 268, 1990, p. 230-239.

Young R. J., Lu D., Day R. J., Knoff W. F., and Davis H. A., " Relationship between structure and mechanical properties for aramid fibres », Journal of Materials Science, 27, 1992, p. 5431-5444. 